\title{
Flesh for fantasy: the future of sado- masochism and performance art in virtual worlds
}

\author{
Lisa Newman \\ 2 Gyrlz Performative Arts \\ Flat 3, 15 A Mauldeth Rd \\ Withington, Manchester M20 4NE \\ lisa@2gyrlz.org
}

\begin{abstract}
This essay explores how the Deleuzian definition of sadomasochism applies to the performance art experience, how re-enactments of physical performance works through the use of surrogate bodies affects this experience, and the evolution of performance art in virtual worlds where the physical surrogate becomes the digital avatar body.
\end{abstract}

Performance art. Sadomasochism. Ron Athey. Re-enactment. Second Life. Surrogate body. Marina Abramovic. Eva and Marco Mattes. Endurance. Body art. Presence.

The ascent from the human body to the work of art and from the work of art to the Idea must take place under the shadow of the whip. (Gilles Deleuze)

\section{SELF-OBLITERATION AND THE PROBLEM OF RE-ENACTMENT IN PERFORMANCE ART}

On 19 March 2010, as part of the thirtieth National Review of Live Art, (an annual showcase of emerging and established performance artists held in Glasgow, Scotland) a little over 150 people (myself included) witnessed the latest installation in a series by Ron Athey entitled Self-Obliteration.

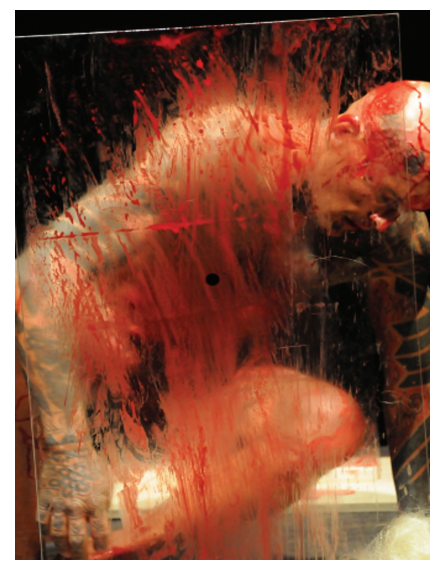

Figure 1: Athey performing Self-Obliteration in 2008
Upon entering the theatre, the audience was invited to form a wide circle around the artist, who was positioned on a high platform in the centre of the theatre where he could be viewed from any angle. Athey's lean and muscular naked body, nearly covered in tattoos which narrate his rich and ragged history, appeared to be hyper-visceral as it glowed under the stage lighting. The performance began with Athey brushing a long, blonde wig that completely obscured his face. As the action continued, he slowly rose, back-combing the wig to uncover his face and meet his reflection in one of four panes of glass that had been placed in an open barrier along each edge of the platform.

What could be interpreted as an image of the tragic Narcissus was erased as Athey removed the wig to reveal several needles inserted into the crown of his head. The glass was abruptly transformed from a reflective tool to a receptacle, as he removed the needles and blood literally and vigorously flowed from his wounds, covering both himself and the glass. This action was repeated until all four panes were opaque with red and the addition of a viscous, semen-like substance, poured from a jar. As Guardian journalist, Lyn Gardner observed:

For those of us who watch - or bear witness, as it so often feels in Athey's performances - it is as if he is trying to obliterate our vision of him with his own bodily fluids. One penetration of the body is followed by another as Athey fists himself; eventually he is quiet, lying hunched in the bloodied glass cage while rock salt pours 
from above. Each tiny lump must be a vicious blow on his skin, but he never flinches. He is perfectly still, like an ancient battered rock: immense, blind and immovable. Buried alive. (Gardner, 2010)

Simultaneously, on the other side of the Atlantic, the juggernaut of the exhibition Marina Abramovic: The Artist Is Present which features a retrospective of the Balkan performance artist's forty years of work at the Modern Museum of Art in New York. This retrospective informally began with the 2005 Guggenheim event Seven Easy Pieces, which featured Abramovic recreating performances by artists such as Joseph Beuys and Gina Pane and heralding the merits of preserving performance art through re-enactment as a way of revitalising and reliving past iconic works; performances that were originally presented as singular, fleeting moments in time; ephemeral and experiential. In defence of the validity of re-presenting these works, Abramovic asserts that 'Reperformance is the new concept, the new idea!. . Otherwise it will be dead as an art form'. (Cypriano, 2009)

Responses to this assertion have understandably been mixed. As several art critics have pointed out, Abramovic's credo is contradictory to the original ethos of the performance art movements in Europe and North America in the 1960s, which focused on a rejection of the museification of art and embraced the temporality of the live experience. 'Ironically', as critic Fabio Cypriano observes,

this project called Seven Easy Pieces went absolutely against the rules established by the artist herself for her performances in the beginning of her career, synthesised in three points: 'no rehearsal, no repetition, no predicted end'. (Cypriano, 2009)

I have included a description of Athey's SelfObliteration to give an example of performative work that would prove challenging to re-enact or preserve under different authorship, or what I refer to in this essay as a 'surrogate body'. Athey gained notoriety in the 1990s for creating public performances in which the spilling of his HIV+ blood and masochistic actions, which added much needed fuel to the political fire surrounding United States government's avoidance of the AIDS epidemic. A crucial element of this kind of extremely personal work is the absence of a theatrical script, or any set of instructions offering direction for a restaging of the piece. There is no rehearsal, no sacred ephemera designed to be kept under museum glass - there is only a brief glimpse into a unique life story that will one day end.
In this essay, I would like to discuss recent concerns regarding the 'preservation' of performance art through re-enactments of physical performance works through the use of surrogate bodies, and the evolution of these re-enactments in virtual worlds where the physical surrogate becomes the digital avatar body, as in the on-line game, Second Life, and the work of Italian artists Eva and Marco Mattes.

Additionally, I would like to examine how both virtual and live re-enactment strategies are being explored to create an effective sense of 'liveness' or 'presence' in performative actions for both artists and audiences, and how the challenges therein are addressed.

Is it possible to translate the physical and psychological elements of a 'real world' live experience virtually through a combination of haptic visuality and the surrogate body of the avatar? Is the physicality, and inevitable mortality, of the performative artist's body crucial to the successful communication of the performance? Or are there other, non-corporeal elements of the performative action that transcend the original, physical experience and can be translated through new technologies and/or re-enactment?

\section{SADOMASOCHISM AND THE PERFORMANCE ARTIST}

I would like to clarify that the artists mentioned in this essay belong to a sub-genre of performance art which is generally agreed on being labelled as 'endurance' or 'body art'. This category is primarily attributed to artists who construct and undergo challenging physical or psychological ordeals through the media of the performative act. In order to better illustrate the complexities of the artist's intention and experience, I will now briefly introduce a parallel to the Deluzian description of sadomasochism in Coldness and Cruelty [1969 (Eng. tr. 1971)].

Deleuze's primary aim with his text is to identify the differences in philosophies between sadism and masochism, that their meanings surpass the simplistic desires of giving and receiving pain and pleasure, and to dispel the myth that one practice is the simple inverse of the other. Rather than shape his analyses purely through a clinical, psychoanalytical lens, he takes 'an entirely different approach, the literary approach, since it is from literature that stem the original definitions of sadism and masochism'. The resulting document of Coldness and Cruelty is an in-depth comparison of the writings of the Marquis de Sade and Leopold von Sacher-Masoch. 
'In the work of Masoch', Deleuze explains:

\begin{abstract}
.. it is all persuasion and education. We are no longer in the presence of a torturer seizing upon a victim and enjoying her all the more because she is unconsenting and unpersuaded. We are dealing with a victim in search of a torturer and who needs to educate, persuade and conclude an alliance with the torturer in order to realise the strangest of schemes. This is why. . .the masochist draws up contracts while the sadist abominates and destroys them. The sadist is in need of institutions, the masochist of contractual obligations. (Deleuze, 1971, pp. 20-21)
\end{abstract}

I would posit that within the practice of the endurance artist, there are elements of both the sadist's desire for the desecration of existing structures in favour of the experimental laboratory of the disciplinary 'institution', and the masochist's need to create educational 'contractual obligations'. De Sade's rejection of, and disillusion with the laws, morals, and societal concepts of normativity in France after the Revolution (1789-1799) are echoed in the post World War I manifestos and actions of the Futurist and Dada movements in the early twentieth century, and in the ethos of later performance movements, including the Vienna Actionists in the 1960s.

Where the Futurists and subsequent performance movements shared a commonality in integrating the artist and the creative work in resistance to the commodification of the art market, the body artists of the 1960s shifted their focus on the action itself as a mode of societal intervention and political dissent, and began to turn inward to explore the political through the personal.

Elaborating further on the ethos of the endurance/body artist, Italian critic Lea Vergine writes:

\footnotetext{
. . they want an intimate acquaintance with all the possibilities of self-knowledge that can stem from the body and the investigation of the body. Most of the time, the experiences we are dealing with are authentic, and they are consequently cruel and painful. Those who are in pain will tell you that they have the right to be taken seriously. (Vergine, 2000, p. 8)
}

The Vienna Actionists (notably: Gunther Brus, Hermann Nitsch, Otto Muehl, and Rudolf Schwarzkogler) were some of the earliest artists who explored physical endurance in their actions. Through acts of debasement such as (but in no way limited to) urination, defecation, and selfcutting, the Actionists explored primal states of human existence. Nitsch's performative rituals, such as the Orgies Mysteries Theatre (1970), involved Dionysian-like animal slaughtering and sexual practice. In later writings, Nitsch explains the philosophy behind these actions in a reminiscently de Sadian language:

the VOLUPTUOUSNESS of the excess, the excessive orgiastic mode of perception, provokes in us a state in which pain and extreme pleasure mingle intimately, where the states of death and life appear to manifest themselves simultaneously in us and no difference may be seen between them (Green, 1999, p. 157)

Here, I interpret Nitsch's Theatre to act as a kind of panacea to the excess of de Sade's 'institution', with the performative act manifesting what political essayist, Hakim Bey, has termed a Temporary Autonomous Zone (TAZ):

The TAZ is like an uprising which does not engage directly with the State, a guerilla operation which liberates an area (of land, of time, of imagination) and then dissolves to itself to re-form elsewhere/elsewhen before the State can crush it. (Bey, 1991)

In other words, the performative act becomes a liminal space, where the lines between art and life, pleasure and pain, madness and sanity can be blurred and explored within a context that offers some leniency from societal normative rules and behaviour - while still allowing room for dissent through the parameters and temperament of the (masochistic) contract.

Within the majority of endurance actions, there is a set of guidelines, a plan, or at the least a series of potentials that the artist creates for themselves which often acts as a kind of contract. In addition to this contractual alliance taking place between the artist and outside parties, the agreement is often an internal one. The contract may stipulate the details of the ordeal: the duration of the piece marked in time or some other indicative event which can signal a beginning or end, the objects used within the piece, the environment in which it will take place, the level of involvement of the audience (if there is one present) - all of which help determine the level of risk in the piece.

Deleuze describes the masochist's contract as a tool used to communicate one's specific desires for ordeals and punishment, and to educate and persuade other parties involved to follow through with their role in the alliance. In the case of the endurance artist, this contract is either solely an internal agreement within the artist, with performative collaborators (as co-conspirators), or with the audience (as witness).

To look at an example of the contract in collaborative endurance art, I would like to refer to the early work of Marina Abramovic and her partner/collaborator Ulay's (b. Uwe Laysiepan), 
titled Relation Work (begun in 1976). Within this series, the duo created a piece titled Imponderabilia, performed in June 1977 at Galleria Comunale d'Arte Moderna, Bologna. The artists created the following outline for the performance:

We are standing naked in the main entrance of the Museum, facing each other.

The public entering the Museum have to pass sideways through the small space between us.

Each person passing has to choose which one of us to face. (Carotti, 1998, p. 30)

The outline describes the agreement between the two artists to follow through together with the imagined action, and the parameters for the audience to participate within the piece. Here, the audience is given the freedom to choose whether or not to interact with the artists, but is faced with a dilemma of how to negotiate their own comfort levels by having to make a decision between which of the artists' naked bodies they must face to be able to enter the museum, and thereby assent to their masochist contract.

In Contract With the Skin (1998) Kathy O'Dell writes:

These artists did not advocate masochism for its own sake but used it to reveal symbolically the structure of agreements that we make as we try to come to terms with an unsettling, indeterminate consciousness of our own bodies. (O'Dell, 1998, p. 16)

Thus, in the context of the endurance artist, the term 'sadomasochism' refers to the sadistic desire to destroy normativity and create a Temporary Autonomous Zone, combined with the need to adhere to a 'structure of agreements' through the masochistic contract. The integrated use of the two creates a modus operandi for the artist to challenge and explore a myriad of potentials through physical actions and interactions.

\section{SELF-PRESERVATION AND THE SURROGATE BODY}

What happens to the contract, the element of risk, the exploration of pain and pleasure, and even the translation of the artist's personal narrative in the performative act when the physical body is absent or represented by a surrogate body? What happens to the sadomasochistic drive to destroy and challenge when the action is repeated by another author in another context?

I would like to explore these questions by discussing the recent trends towards performance re-enactment and the potentials for virtual worlds to create a hybridisation between the mediated, noncorporeal interaction and the direct, live experience.

In January of 2010, Abramovic co-curated the Pigs of Today are the Hams of Tomorrow with the Plymouth Art Centre in Devon, England. The weekend symposium involved panel discussions on the topic of performance preservation, included presentations of live actions by established and emerging artists, and was essentially designed as one of several promotional events which lead to the anticipated 2012 opening of the Marina Abramovic Institute for the Preservation of Performance in New York.

A project developed within the symposium was The Performance Re-enactment Society (PRS) who are self-described as:

an occasional collective of artists, archivists and researchers, who use archival documents and audience's memories to revive past art experiences and create them anew. Their collaborative performance re-enactments are acts of conservation and transform past works into new events. (PRS, 2010)

Over the course of the symposium, the PRS created a softer, looser version of Abramovic's 2005 Seven Easy Pieces series, by re-enacting numerous works by past and present artists. One notable difference within the represented actions of the PRS and those of Abramovic, was that the group re-created these actions without having received permission to do so from the original artists - which was a crucial stipulation of the Abramovic re-enactment 'contract' which states:
Ask permission to the artist
Pay copyrights to the artist
Make a new interpretation of the piece
Display original material: photographs, video, objects
Display the new interpretation of the piece (Cypriano, 2009)

She explains the thinking behind this contract and the resulting re-enactments as:

a way to take charge of the history of performance'. In the 1990s, as younger artists became interested in work of the '60s and '70s, she said she noticed that some were restaging historical works themselves, often without consulting or even crediting the originator. 'I realised this is happening because performance is nobody's territory,' she said. 'It's never been mainstream art and there's no rules'. Finding this unjust, she decided to set them herself, by recreating the works in consultation with the 
relevant artists and estates. Better she should do it now, she said, because 'they will do it anyway when you're dead behind your back'. (Kino, 2010)

Outside of the commercial concerns of the larger 'art market' inherent in the language, I find this last quote to offer some insight into Abramovic's potential incentive for replacing the ethos of performance as 'nobody's territory' with a corralling of a selection of performance artists into a series of metonyms, and subsequently creating a copyrighted history of performance art, sanctioned by the Marina Abramovic Institute. It would appear that outside of Abramovic's desire to historically position herself as a kind of 'meta-artist' from which all subsequent performance art has sprung, her mission to preserve works originally created as ephemeral experiences is perhaps a way of placating a fear of loss, of avoiding future misrepresentation - a grasp at some form of immortality.

And yet it is the mortality of the artist body and the temporality of live actions which has historically been critical in defining the 'liveness' or 'presence' of performances.

In her introductory essay to the forthcoming publication, Archaeologies of Presence: Acting, Performing, Being (2010) art historian, Amelia Jones discusses the paradox of 'presence' in live performance art. She asserts that presence is elusive in the live action, as it is the action's

durationality (the fact that it enacts the body as always already escaping into the past) [which] points to the fact that there is no 'presence' as this is commonly understood. (Jones, 2010)

What I interpret this to mean is that despite the durational, time-based experience for both the artist and the audience, there is no fixed present moment with which to inhabit as viewers, as we are constantly in the process of mentally archiving and preserving the action in memory. Applying this theory to the problem of authenticity within performance re-enactment, Jones argues:

\begin{abstract}
. . . the re-enactment activates precisely the tension between our desire for the material (for the other's body; for 'presence'; for the 'true event') and the impossibility of ever fixing this in space and time. The re-enactment both testifies to our desire to know the past in order to secure ourselves in the present and the paradox of that knowledge always taking place through repetition. And thus the paradox of that knowledge proving our own inexorable mortality: the fact that we are always reaching to secure time, and always failing. (Jones, 2010)
\end{abstract}

It is this failure of capturing the live moment; the peak experience of the performative action, the
T.A.Z., that brings us to the question: Can the essence of a performance be translated without the original author's physical body, and is re-enactment a grasp at an ephemeral experience, relived as imitation through a surrogate author?

This dilemma recalls Solveig Dommartin in the Wim Wenders film, Until the End of the World (1991) who becomes overwrought with addiction as she obsessively watches and replays a video of a captured dream through a futuristic recording device; her madness reaches a crescendo when the batteries die and the dream is lost forever.

As numerous critics and theorists have argued, the majority of performances are experienced through mediated documentation, with only a limited audience experiencing the original live action. Revisiting the examples presented here of physical endurance performances, I posit whether or not the psychological and aesthetic elements of the work can be resurrected through the surrogate body of a new (physical or virtual) author, in a new live action in order to 'preserve' it for new audiences? Or is this an impossibility, due to an inseparable connection of the psychological and emotional experience of the action from the original author?

Is it possible that the re-enactment and the original performance are so different in ethos, intention, and efficacy that they should actually be considered two entirely separate forms of artistic expression?

To explore these ideas further, I would like to introduce the example of the work of collaborative duo, Eva and Marco Mattes, also known as 0100101110101101.org, and their re-enactment of Abramovic and Ulay's Imponderabilia through the use of avatars in the on-line game of Second Life.

The performance was presented to both virtual and 'real' world audiences through video projection and other Second Life avatars as part of the Mattes' Synthetic Performances series presented at the biennial 2007 Performa exhibition in New York. The naked avatars depicted the Mattes' as their own representations, and other avatars were invited to pass through the 'fleshy' gate in a recreation of the original 1977 action. Here the surrogate body is twice-removed from the original: The Mattes' become the new interpreters of the action, and then actualise this through virtual extensions of themselves as avatar representations.

By inserting the surrogate body into the virtual world, several issues arrive which differ greatly from non-virtual re-enactments. The first is the element of risk. In the original 1977 piece, it was largely the physicality of the artists that instilled a sense of anxiety in the audience participants. 
In addition to Jones' paradox of 'presence', I would posit here that because of the dynamic level of risk and interaction that was demanded of the audience in the original piece, time was negotiated not only in terms of 'now' and 'past', but also involved a negotiation of the immediate future. The terms of the artist/audience contract are living here as the participant must not just be present as passive witness, but negotiate their participation on a physical and psychological level: 'How and will I choose to be involved, how will I affect the performance and be affected myself through my participation?'

In the Mattes' re-enactment, the level of physical risk is seemingly all but absent for the noncorporeal avatars. However, what comes about as a result of this are artist/audience interactions which did not exist in the original work. As art critic Rachel Wolff observed:

Everything followed the lines of the original performance, until some of the patrons stripped down, too; one seemed to be getting fresh with avatar Eva, displaying the heightened expressiveness typical of the virtual realm. (Wolff, 2008)

The masochistic contract is re-negotiated here, and experiences of pain and pleasure in the physical body are subsumed by fantasy and a haptic visuality of interaction and 'heightened expressiveness' which can be explored ad infinitum within the possibilities allowed by available technology.

Haptic visuality, as termed by critic Laura Marks, is explained 'as a kind of seeing that uses the eye like an organ of touch' (Marks, 2004, p. 82). In virtual arenas, this kinaesthetic experience depends somewhat on the level of realism in the images created, and/or the suspension of disbelief allowed by the user when transferring real world sensory experiences to the on-line avatar.

The Mattes' embraced this suspension of disbelief, as well as the power of the haptic response in digital imagery in their 1999 project, Darko Maver. The piece fictionalised the life and performances of the radical Serbian artist, Maver, who had reportedly died in prison on the Kosovo border after being arrested for creating and documenting hyperrealistic wax representations of gruesome murder victims and leaving them in hotels and empty buildings in former Yugoslavia. Before the artists revealed that the project was actually a hoax, and Maver a fabricated character, Maver had (posthumously) reached a nearly cult status in the media and art world, and an exhibition of his work was included the $48^{\text {th }}$ Venice Biennale.

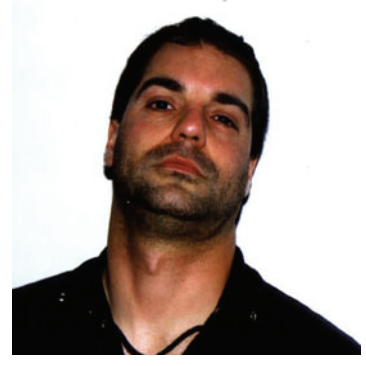

Figure 2: Darko Maver - Portrait of the nonexistent artist (1998)

However, once it was revealed that the life of Maver was a constructed avatar:

\begin{abstract}
a further revelation turned red faces sickly pale: the horrifically maimed, bleeding and decapitated waxwork figures Maver had made his name with - photos of which had been widely circulated - weren't models at all, but rather photographic documents of actual atrocities, several of which had taken place in Maver's 'home' patch of the former Yugoslavia. (Veen, 2000)
\end{abstract}

I would appear that it was the extreme visceral nature of the images - both in their fictionalised form as wax recreations, and the revelation of their true narrative as documentation of actual atrocities - that led to the subsequent sensationalism generated by curators and critics. Had the story of Maver been that of an apolitical aesthete, and the images presented pastoral landscapes, the audience's haptic experience would likely not have been dramatic enough to have generated the emotional response necessary for the success of the project.

As a result, the Mattes' prank became a successful form of political activism. In addition to drawing attention to the real atrocities of the Balkan war, the performance also provided a critique on the influence of the power of the mediated image which was twofold:

to point out the artificial nature of this world [and] the role played by critics and curators to establish the success or failure of artists. . . (Caronia, 2000)

What is exposed by the Darko Maver project is the desire for authenticity versus the enticement of the fantasy. In our search for 'real experience' in a heavily mediated culture, how readily are we willing to embrace the gesture of an action or event, even if the evidence needed to determine its truthfulness is lacking or absent? Was the Maver illusion easy to be believed because, fictional or real, it acted as a catalyst for new public discussions around the horrors of war and the Balkan genocide? Deleuze writes: 
[the masochist] does not believe in negating or destroying the world nor in idealising it: what he does is to disavow and thus to suspend it, in order to secure an ideal which is itself suspended in fantasy. He questions the validity of existing reality in order to create a pure ideal reality, an operation which is perfectly in line with the judicial spirit of masochism. (Deleuze, 1971, pp. 32-33)

The political commentary of the Serbo-Croatian war was genuine, and though the only representation of the physical Maver was accessible through fabricated digital portraits, the gesture of the Mattes' performative actions and their commentary on the horrors of war through Maver impacted audiences and critics with a similar force, and intention as other performance work generated by 'real' artists in the physical world.

Re-directing this question of the gesture to Athey's physical ordeal in Self-Obliteration - is it possible for the impact of the live experience be translated through a documentation with the intensity of work made for and by virtual means? Can the invisible threat of the virus in Athey's spilled blood be translated into gesture? Or does the risk inherent in the live interaction, and the audience member's agreement to engage in Athey's masochistic contract as witness, create an irreducible state of heightened, full-sensory experience which cannot manifest anywhere but during the live act?

Referring to the Deleuzian philosophy presented earlier, it would be a fair assumption that if the artist has introduced the performance into a public setting, it is because of the desire for an action to be witnessed, or for direct interactions with the audience to occur. In the endurance artist's contract, the physical body is often the arena where the artist's internal struggle is made visible and reaches out, either directly or haptically, to make human contact and externalise the internal pleasure/pain dilemma into something tangible.

If performance art is indeed rooted in the artist, their internal and external contracts, and an inherently transitory 'liveness' and 'presence', then the actions being made through new technologies and re-enactment would appear to be inherently different work. Ideally, the new language being developed to discuss the nature of this work will aid it in its ability to manifest its various aims, rather than simply clinging to a genre that may not be its appropriate home.

Perhaps it is time to begin looking through a lens of post-performativity to understand what may be entirely new genres emerging, and to allow them to evolve simultaneously along existing practices, rather than as an adversarial struggle to preserve that which is inherently transitive.

\section{REFERENCES}

http://www.0100101110101101.org (30 March

http://www.2ndlive.org (30 March 2010)

Bey, H. (1991) T.A.Z. Autonomedia: New York.

Caronia, A. (2000) from l'Unità 14 February 2000. http://www.0100101110101101.org/texts/unita mav e1-en.html (30 March 2010)

Carotti, E. and Lutz, F. eds. (1998) Artist BodyMarina Abramovic Edizioni Charta: Milano.

Cypriano, F. (2009) Performance and reenactment: analyzing Marina Abramovic's Seven Easy Pieces. Posted by author on idanca.net on 2 September 2009. http://idanca.net/lang/enus/2009/09/02/performance-e-reencenacao-umaanalise-de-seven-eeasy-pieces-de-marinaabramovic/12156/ (30 March 2010)

Deleuze,G. (1971) Coldness and Cruelty. Reprinted in Masochism (1989) Zone Books, New York.

Gardner, L. (2010) National Review of Live Art. http://www.guardian.co.uk/stage/2010/mar/22/natio nal-review-of-live-art (28 March 2010)

Green, M. ed. (1999) Brus Muehl Nitsch Schwarzkogler - Writings of the Vienna Actionists. Atlas Press: London.

Jones, A. (2010) The Artist is Present: Artistic Reenactments and the Impossibility of Presence. In Archaeologies of Presence: Acting, Performing, Being, Kaye,N. ,Giannachi, G. and Shanks, M. eds. (forthcoming 2010 - publisher details and page numbers not available. Text supplied by author.)

Kino, C. (2010) A Rebel Form Gains Favor. Fights Ensue. Nytimes.com 14/03/2010 edition. http://www.nytimes.com/2010/03/14/arts/design/14 performance.html?scp=7\&sq=marina\%20abramovi c\&st=cse (24 March 2010)

Marks, L. (2004) Haptic Visuality: Touching with the Eyes. Framework:the finnish art review issue 2. 2004

O'Dell, K. (1998) Contract With the Skin University of Minnesota Press, Minneapolis.

PRS (2010) Performance Re-Enactment Society Facebook page. http://www.facebook.com/home.php?\#!/group.php? gid=36004433478 (29 March 2010)

Until the End of The World (1991) Film information for 'Until the End of the World'. Directed by Wim 
Veen, A. (2000) The Death and Death of Darko Maver. Mute. n. 17 June 2000.

http://www.0100101110101101.org/texts/mute ma ve-en.html (30 March 2010)

Vergine, L. (2000) Body Art and Performance: The Body as Language Skira Editore: Milan

Wenders. Argos Films. http://www.wimwenders.com/movies/movies spec/untiltheendofth eworld/untiltheendoftheworld.htm (31 March 2010)

Wolff, R. (2008) All the Web's a Stage. ARTnews Vol. 107, Number 2. February 2008 http://www.artnewsonline.com/issues/article.asp?ar $\underline{\mathrm{t} i \mathrm{~d}=2443}$ (16 November 2008)

\section{FIGURES}

Figure 1: Ron Athey performing Self-Obliteration on April 1, 2008 in Portland, Oregon. Photograph by Circle 23 for 2 Gyrlz Performative Arts.

Figure 2: Darko Maver - Portrait of the nonexistent artist (1998) print ready version available for public download

http://www.0100101110101101.org/download/dark o maver.html (30 March 2010) 